\title{
The evolution of the atmosphere in the Archaean and early Proterozoic
}

\author{
NISBET Euan* \& FOWLER C Mary R \\ Deptartment of Earth Sciences, Royal Holloway, University of London, Egham, Surrey TW20 OEX, United Kingdom
}

Received September 13, 2010; accepted September 26, 2010

\begin{abstract}
Key steps in atmospheric evolution occurred in the Archaean. The Hadean atmosphere was created by the inorganic processes of volatile accretion from space and degassing from the interior, and then modified by chemical and photochemical processes. The air was probably initially anoxic, though there may have been a supply of oxidation power as a consequence of hydrodynamic escape to space of hydrogen from water. Early subduction may have removed $\mathrm{CO}_{2}$ and the Hadean planet may have been icy. In the Archaean, as anoxygenic and then oxygenic photosynthesis evolved, biological activity remade the atmosphere. Sedimentological evidence implies there were liquid oceans despite the faint young Sun. These oceans may have been sustained by the greenhouse warming effect of biologically-made methane. Oxygenesis in the late Archaean would have released free $\mathrm{O}_{2}$ into the water. This would have created oxic surface waters, challenging the methane greenhouse. After the Great Oxidation Event around 2.3 to 2.4 billion years ago, the atmosphere itself became oxic, perhaps triggering a glacial crisis by cutting methane-caused greenhouse warming. By the early Proterozoic, all the key biochemical processes that maintain the modern atmosphere were probably present in the microbial community.
\end{abstract}

Archean, atmosphere evolution, photosynthesis, methane, stromatolite, Hadean

Citation: Nisbet E, Fowler C M R. The evolution of the atmosphere in the Archaean and early Proterozoic. Chinese Sci Bull, 2011, 56: 4-13, doi: 10.1007/s11434010-4199-8

Though the boundaries are not fully defined, Earth's history is divided into four aeons: Hadean (4.5 to $\sim 4 \mathrm{Ga}$ ago, where $1 \mathrm{Ga}=10^{9}$ years, also known as a Giga-annum, Ga), Archaean ( 4.0 to $2.5 \mathrm{Ga}$ and the main focus of this review), Proterozoic (2.5 to $0.54 \mathrm{Ga}$ ) and Phanerozoic (since 0.54 Ga) (Figure 1). Recently an earliest aeon, the Chaotian, has been suggested [1]. This would cover the time during which the solar system was forming.

The Hadean is, broadly speaking, the time after the Moon-forming impact that marked the end of the main accretion of the Earth, and before the start of life and the geological record [1]. Alternately, it can be taken as the time from 4.5-4.0 Ga ago. Initially, during the Hadean, the atmosphere was entirely the product of physical and chemical processes-any volatiles from the accretion of the planet

*Corresponding author (email: e.nisbet@es.rhul.ac.uk) that survived or post-dated the Moon-forming impact, and probably largely from the degassing of the interior. This atmosphere would be modified by photochemical action by sunlight, and by interaction with crustal rocks and magma, both from volcanoes and following large meteorite impacts.

Most likely the dominant gases in the very earliest air were carbon gases such as $\mathrm{CO}_{2}$ and water, whether as ice, liquid or vapour. However, if subduction of the ocean floor began early in the planet's history, a significant part of the degassed $\mathrm{CO}_{2}$ could have been reincorporated relatively quickly (within a few hundred million years or less) into altered ocean floor volcanic rocks and then subducted into the interior (see discussion in [2]). In this case, the planet's surface may have been icy.

At some stage perhaps between 4.2 and 3.8 Ga ago, life began. Immediately, life creates organic waste. Biogenic gases would have been added to the ocean/atmosphere system, and 

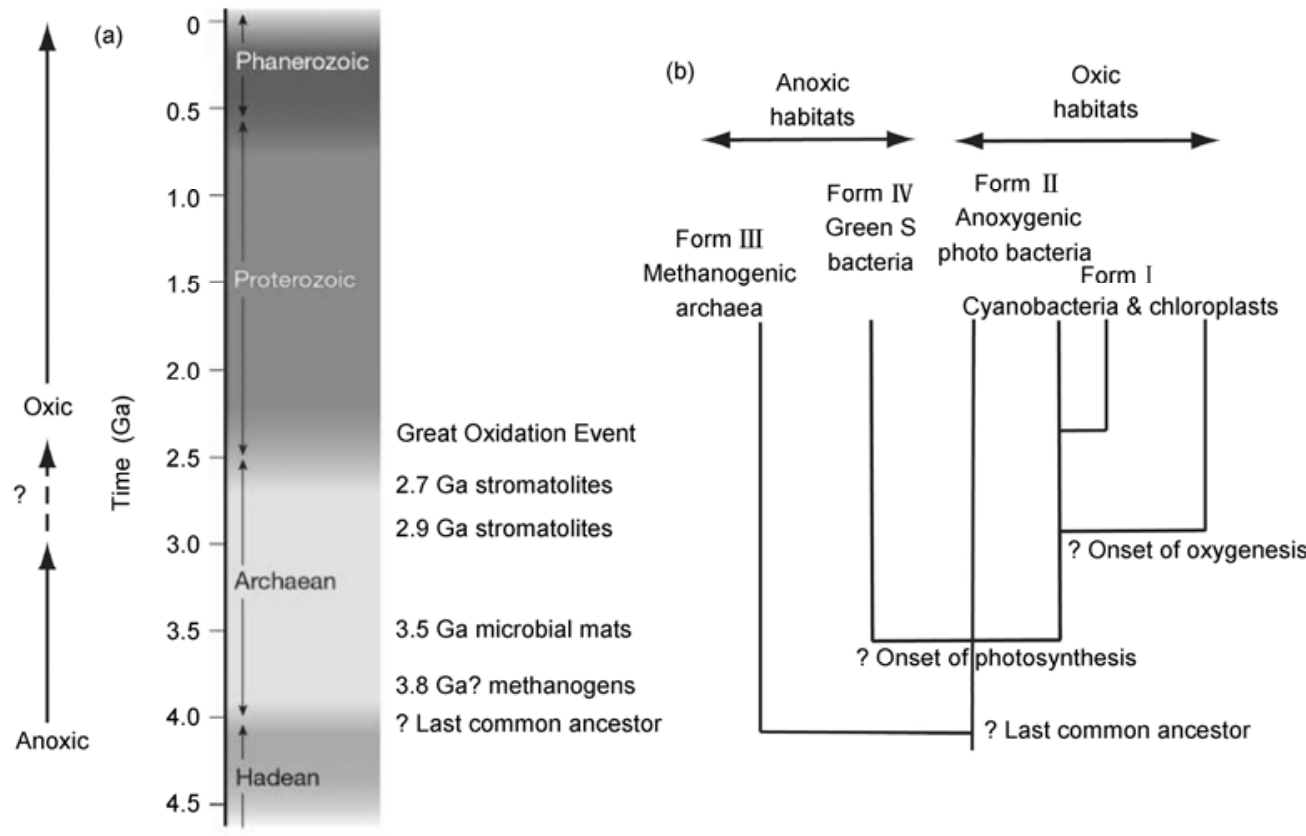

Figure 1 (a) Geological aeons (from [3]). Note that the Greek word transliterated "Archaean" in Latin and UK English is normally concatenated to "Archean" in US spelling. Both spellings are correct. (b) The forms of rubisco. Forms III, and rubisco-like protein Form IV occur in anaerobic organisms and may be older in evolutionary terms. Form II in anoxygenic bacteria and Form I in cyanobacteria and plant chloroplasts both occur in aerobic organisms. From [4].

as a result other chemical species would have formed in the air, including organic aerosols. Among the new chemical species the most interesting would have been methane, and perhaps also $\mathrm{N}_{2} \mathrm{O}$ and maybe COS. This would have begun the first major period of biological management of the air.

A second great change then took place. The evolution of oxygenic photosynthesis produced quantities of oxygen as a waste product, dangerous to much of the life extant in the Archaean. Eventually the air became oxic with the waste oxygen. This was the Great Oxidation Event, which took place in the early Proterozoic aeon about 2.3-2.4 billion years ago (see [5] for a history of oxygen in the air). Since then, free oxygen has been present in the air. As an indirect result, methane has become a trace species. Waste that is dangerous to microbial life presents an opportunity for other cells. Throughout the Phanerozoic, the oxygen content has been high enough to sustain animal life. Today, the air is one-fifth oxygen and four-fifths nitrogen, both biogenic.

(i) Management of the air. The air today is made and managed by life: life has furnished its own home. Unlike the other major geochemical reservoirs, the atmosphere is small, fragile, quickly and easily changed. Over the aeons, life has so modified the products of volcanic degassing that the atmosphere has become a biological construction, managed by living organisms. The modern air, excepting the argon, is made and controlled by biochemical reactions that first evolved in Archaean bacteria and archaea. This sets the surface conditions of the planet and influences the evolution of the interior.
The major gas in the air, dinitrogen, $\mathrm{N}_{2}$, is emitted by diverse bacteria, including both the anammox planctomycetes (which may be very ancient) and the denitrifying bacteria. On the natural (pre-industrial) world their output was probably equally balanced by uptake during nitrogen fixation, so the $\mathrm{N}_{2}$ content was stable. Most nitrogen fixation is biological, but $\mathrm{N}_{2}$ is also fixed by lightning: this flux depends on the water vapour content of the air, which in turn depends on the greenhouse gases. Achieving a balance between nitrogen fixation and emission sets the mass of nitrogen in the atmosphere, and hence the pressure of the air, which influences greenhouse warming. The nitrifying and denitrifying reactions are probably very old. Nitrous oxide, a potent greenhouse gas, is also part of the nitrogen cycle. The distribution of nitrogen between atmosphere, the earth's crust, and the planetary interior is not well constrained. Goldblatt et al. [6] estimated that the continental crust contains $1 \times 10^{18}-2 \times 10^{18} \mathrm{~kg} \mathrm{~N}$, much of which it may have collected since $\sim 2.7 \mathrm{Ga}$ ago. The mantle may contain more.

Oxygenic photosynthesis may have evolved 2.9 billion years ago or earlier $[7,8]$, from prior anoxygenic photosynthesisers [9]. The first oxygen-emitter must have been an ancestral cyanobacterial cell, distantly related to the very diverse array of modern cyanobacteria. Diversification was likely very rapid in the late Archaean (2.9 to 2.5 billion years ago) [3]. Some of the early cyanobacteria probably lived as "stromatolites" (layered sediments made by biofilms), while other cells probably quickly evolved to fill the niche for free-living plankton. Chloroplasts in modern 
algae and plants are descended from early cyanobacteria that were symbiotic with ancestral eukaryote cells. Just as astronauts can walk on the Moon in space suits, so the cyanobacteria within plants are wearing "land-suits", and thereby can even occupy the desert places of the continents.

Biological respiration consumes oxygen to produce $\mathrm{CO}_{2}$. The oxygen content of the air represents the balancing level between photosynthetic emission and respiratory uptake. The carbon dioxide uptake is the obverse side of the coin: $\mathrm{CO}_{2}$ is given out by respiration and fixed by photosynthesis, while emission of equivalent moles of oxygen is the reverse. Most of the fixed carbon in organic matter is quickly respired again, but some of the $\mathrm{C}$ is sedimented as organic debris into seabed mud. In the organic-rich mud deposit, available oxidation power is quickly consumed. Methane, which is arguably the most interesting of the greenhouse gases, is emitted by methanogenic archaea, which thereby return the organically fixed carbon to air. Hence their productivity is indirectly linked to the amount of respiration and photosynthesis. In the modern world, some of the emitted methane is destroyed in the upper layers of the sediment by anaerobic microbial oxidation. Other methane is oxidised aerobically in the topmost mud. Methane bubbles passing upwards in water are today microbially oxidised by methanotrophs. For methane that does enter the air, the atmospheric oxidation power wins. Atmospheric methane is destroyed by $\mathrm{OH}$ (which is created from water in the oxygen-rich air by photolysis), and is also taken up by methanotrophic bacteria in soil.

In the air, only argon is abiotic, emitted by radioactive decay of crustal rocks. Yet even the argon emission is indirectly controlled by water, as it is liberated by erosion of potassium-rich rocks, themselves created in magmatic events, many of which depended on subduction of oceanic water.

The total mass of the atmosphere is small $-1 \mathrm{~kg} \mathrm{~cm}^{-2}$ of surface area. This means that atmospheric composition can easily be altered by biogeochemical or volcanic processes, acting over a few tens of millions of years. In the Archaean geological record, where a million years is as a moment, atmospheric change is not gradual. Isotopic data suggest change comes relatively abruptly, a shifting of the gears on the geochemical engine. The controlling mode of operation can change suddenly and catastrophically. Swift change is not only an Archaean phenomenon. It has happened in the past twenty thousand years in the glacial-interglacial changes and in the great warming event on the Palaeocene-Eocene boundary 55 million years ago, which may have been driven by methane emissions (e.g. see [10]). Further back in the past, the Earth has been through great cold crises ("snowball Earth events"), for example in the late Precambrian 600-700 million years ago. Even more major was the reconstruction of the entire atmosphere in the Great Oxidation Event, 2.3-2.4 billion years ago [5].

(ii) Rubisco and Nitrogenase. Two families of enzymes manage the atmosphere: these are the rubiscos and the nitrogenases. The atmospheric greenhouse is mainly the product of gases managed by these enzymes.

Rubisco is of great antiquity [11], and nitrogenase probably also. Rubisco (ribulose 1,5-bisphosphate carboxylase/ oxygenase), as its name implies, can work either way, to capture $\mathrm{C}$ into life from $\mathrm{CO}_{2}$ in the air (and thereby permit oxygen emission), or to assist in its respiration out of life into the atmosphere (and thereby permit oxygen-burning).

There are several forms of rubisco and rubisco-like-proteins [10]. Form I enables oxygenic photosynthesis. It occurs in cyanobacteria and chloroplasts in algae and plants, and may have evolved about 2.9 billion years ago [8]. Rubisco's Form II occurs in aerobic anoxygenic photosynthetic bacteria. Form III is found in anaerobic organisms, both bacteria and archaea such as methanogens, while Rubisco-like proteins (Form IV) occur in anaerobic bacteria.

Nitrogenase occurs in nitrogen-fixing bacteria and archaea and is the key enzyme in nitrogen fixation from $\mathrm{N}_{2}$ in air into life. It ranks among the most abundant proteins in the biosphere. Nitrogenase consists of two proteins, an iron protein and an iron-molybdenum protein. It is very sensitive to molecular oxygen, which can irreversibly inactivate it. Nitrogen fixation is metabolically very expensive and very costly in hard-to-acquire elements like iron. Yet, like rubisco, nitrogenase appears to be very inefficient.

(iii) Greenhouse warming. Over time, the Sun steadily brightens as it ages (e.g. see [2]). It was much fainter in the Archaean than now. Even today, under a strong old Sun, the Earth verges on glaciation. Yet sedimentary deposits occur throughout the geological record, showing that liquid water oceans have existed throughout the past 4 billion years, except possibly in rare "snowball" events. One possibility is that this record implies that to sustain liquid oceans, the natural greenhouse warming effect of the air was larger in the past, and that this warming increment has been reduced over time, so maintaining a steady surface environment by compensating for the increase in solar insolation. Another possibility discussed further below, is that albedo was different.

\section{The Hadean atmosphere}

The end of the proposed Chaotian aeon can be taken as the time of the great Moon-forming impact [1,12], when the proto-Earth was struck by a planet about the size of Mars, roughly $4.5 \mathrm{Ga}$ ago. The impact probably melted the entire planetary mantle, and ejected a vast debris of splatter, some of which formed the Moon, though much fell back to Earth. It also may have removed much of a deep primaeval inventory of volatiles, then replaced by secondary degassing by volcanism from the molten interior.

The impact spun and tilted the Earth, imparting the 
angular momentum that today, after billions of years of tidal dissipation, gives us a 24-h day and clearly defined winter and summer seasons. Both the day/night cycle and the seasonality are key factors in the habitability of the planet, giving equable temperatures to all longitudes and most latitudes, and a small pole-to-equator thermal gradient. In short, the impact 4.5 billion years ago determines the length of day, weather, tides, phases of the Moon and eclipses in 2011.

At the start of the Hadean, the early Earth was bombarded by planetesimals up to several hundred kilometres in diameter. Sleep et al. [13] pointed out that under the weak early Hadean Sun, Earth's surface may have been icy, except immediately after great impact heating or volcanic events. The oldest material known on Earth is in zircon crystals from Western Australia, preserved as detritus in younger sediment. These crystals are up to 4.3 to $4.4 \mathrm{Ga}$ old, and must have formed in very early continental material [14]. Magmas containing zircons typically form as a consequence of subduction (i.e. cold dense oceanic plate falling back into the planetary mantle). The oxygen isotope geochemistry of the very old zircons implies that the surface was covered in cool water oceans [15]. For very long periods the planetary surface may have been frozen water ice, losing heat to space. Deep under the ice and insulated by it, warm water would have existed above the many active volcanic vents, fed with hot highly magnesian lava from the molten mantle.

At intervals of millions to hundreds of million years in the Hadean, one or more great impacts would have occurred, when the Earth was hit by bodies say, 200-300 km in diameter. If such a body did hit the planet, the energy from the impact and resultant volcanism would be capable of vaporising the entire surface water inventory [13] by heating the water to $350^{\circ} \mathrm{C}$ or more (when the whole ocean boils, air pressure rises to 350 bars). After such events, for a few thousand years the air would be steam, then it would condense to a brief liquid ocean phase, then return to ice. Smaller impacts, by bodies of 100-200 km, would be capable of heating the ocean to $100^{\circ} \mathrm{C}$ or more, sterilising any early life. Thus any surface life that evolved at this time would not last long - it would be killed in the freeze-fry cycle. Sometime between about 4.2 and $3.6 \mathrm{Ga}$ ago, the bombardment ran out of ammunition [16]. In the period from 4.4 to $3.8 \mathrm{Ga}$ ago, one possibility is that there may have been only few or no giant impacts and Earth may have been comparatively peaceful. Indeed, impacts could have been beneficial in stirring up hydrothermal processing. If so, the origin of life could have taken place at any time between 4.4 and $3.85 \mathrm{Ga}$. If the first life existed in the crevices of deep hydrothermal systems, then it may have been protected from all but the very largest impacts. Ryder found no justification for the claim that life originated as late as $3.85 \mathrm{Ga}$ in response to the end of hostile impact conditions. Since then, though large impacts have occurred, the Earth's water has not been sterilised.

\section{Early to mid-Archaean life: anoxygenic photosynthesis}

The oldest rock on Earth (as distinct from relict crystals after erosion and redeposition) is arguably (there are other claims) the Acasta gneiss, from NW Canada [17]. This is roughly $4 \mathrm{Ga}$ old, latest Hadean.

The oldest large-scale rock suite, formed around 3.8 to $3.6 \mathrm{Ga}$ ago, is the Isua Greenstone belt, in what is now west Greenland. A "greenstone belt" is a collection of rocks typically around $30-50 \mathrm{~km}$ long and 10-20 km across, sometimes much larger, that formed on the Earth's surface and which still recognisably retains features of its original character. All old rocks are metamorphosed, but greenstone belts have relatively low-grade metamorphism (i.e. heated to say no more than a few hundred centigrade, so that many of their minerals are green in colour) and deformation has not destroyed original textures. In the Isua belt, a wide range of original features such as sedimentary and volcanic textures can be recognised. Although there are other examples of very old, highly metamorphosed material, Isua is the oldest major area on the Earth's surface that has been well preserved.

Though there are other claims, it is in Isua that the earliest presumptive evidence for life on Earth is found. Some rocks contain carbon dust that is highly fractionated isotopically, rich in ${ }^{12} \mathrm{C}$ [18]. Such fractionation is characteristic of biological processes. It is possible that this dust could have been made abiotically in space before falling to Earth, but this is very unlikely, given the abundance of the carbon and the sedimentological facies. The simpler explanation is that it comes from dead plankton. In other Isua rocks, sulphur isotopes [19] also suggest biological activity. Sulphate reduction may date from this time and pyrite is present. Methanogenesis, which leaves a record of highly fractionated $\mathrm{C}$ isotopes, may also be very old.

In general, early Archaean life may have existed in the proximity of submarine hydrothermal systems at the rock/ water interface. Here magmatic chemical species, derived from the somewhat more reduced mantle of the planet, came into contact with the somewhat more oxidised chemistry of the ocean/atmosphere system. At the top of the atmosphere, hydrogen loss to space may have provided net oxidation power, and lightning could have fixed nitrogen. The date of the earliest photosynthesis is unknown. It seems likely that the first photosynthetic organisms were anoxic, using $\mathrm{H}_{2}, \mathrm{H}_{2} \mathrm{~S}$ or $\mathrm{CH}_{4}$, or $\mathrm{FeO}$ for example.

The mid-Archaean record comes mainly from the Barberton Mountain Land in South Africa, and the Pilbara in Western Australia. A wide variety of organo-sedimentary rocks has been described. Though most interpretations are controversial, it is very likely that microbial life was abundant. In 
the Pilbara, the $3.45 \mathrm{Ga}$ Strelley Pool Chert has well-preserved, widespread, long-lived stromatolites (characteristic laminated textures, often built by microbial consortia) in a reef laid down in a lake [20], in an anoxic setting. Evidence for photosynthetic microbial mats $3.4 \mathrm{Ga}$ ago also occurs in the Barberton belt, South Africa [21].

Although it is possible that oxygenesis dates back as far as Isua times [22], but see also [8], much of the 3.5 to 3.0 Ga old mid-Archaean evidence suggests anoxic conditions, with a $\mathrm{CO}_{2}$-rich atmosphere [23]. This is consistent with the suggestion that anoxygenic photosynthesis came before oxygenic [9]. The presence of sedimentary sulphides that show mass independent fractionation of Sulphur-33 strongly implies there was no oxygen in the early to mid-Archaean air [24].

Most likely, the top layers of mid-Archaean biological communities were dominated by anoxygenic photosynthetic bacteria using the enzyme Rubisco II. It is possible that a full microbial sulphur cycle operated, with both sulphate reduction and photosynthetic sulphide oxidation. However, though isotopic evidence suggests sulphate reduction was abundant [19], the return process is more difficult to prove as isotopic fractionation is small.

The mid-Archaean geological record includes widespread sediments laid down by liquid water. It is possible that the climate was very warm $\left(70^{\circ} \mathrm{C}\right)[25]$ though there is no consensus on this. Whatever the temperature of the ocean, it was liquid. Given that the Archaean Sun, in which less dense hydrogen was more abundant than now, was fainter than today, the maintenance of warm temperatures implies there must have been a powerful atmospheric greenhouse. This would most likely have been sustained by both methane and $\mathrm{CO}_{2}$, emitted by biological sources (i.e. methanogens). Carbon isotope evidence for fractionation by methanogenic archaea (e.g. see [8]) supports this contention, strongly suggesting the presence of methanogens and hence methane emission. If the atmosphere were anoxic, then the methane would have had a long lifetime in the air and would have accumulated.

\section{Late Archean life: oxygenesis}

Around 2.9 Ga ago, quite different rocks appeared. These were large microbial carbonate reefs, not greatly different from modern examples extant today in places like Shark Bay, Australia. They occur as "stromatolites" (sedimentary structures built by microbial consortia) at Steep Rock in Canada (Figure 2), where the reef is kilometres long [26], in the Pongola Belt in South Africa [27], and at Mushandike in Zimbabwe [28]. All three sequences are, coincidentally, dated as over $2.83 \mathrm{Ga}$ old: the rounding of $\sim 2.9 \mathrm{Ga}$, approximating the likely age, is used here for convenience.

In these examples, the reef material is sedimentary carbonate, including abundant limestone, and has formed in shallow marine settings, implying the water was not markedly acid, and by implication that the $\mathrm{CO}_{2}$ level in the air was modest. There is evidence from $\mathrm{Mo}$ and $\mathrm{Fe}$ isotopes that the water was locally oxic, not anoxic [29], and S-33 evidence also suggests oxic episodes in the Archaean [30]. Carbon isotopes in organic matter in the rocks strongly suggest capture from the atmosphere by Rubisco I-using cyanobacteria: the start of oxygenic photosynthesis [8].

Here lies a problem. The high organic productivity that must have sustained the reefs would have extracted carbon dioxide from the air. Release of oxygen into the air would have supported photochemical reactions that led to the destruction of methane in the air. Both processes would have reduced the greenhouse warming, risking glaciation. Indeed, in the Pongola succession, and in other rocks in South Africa, there is possible evidence of glaciation at this time. If oxygenic photosynthesis by cyanobacteria evolved around $2.9 \mathrm{Ga}$ ago [8], its onset may have been associated with the first signs of glaciation in these 2.9 Ga rocks in southern Africa.

Around $2.7 \mathrm{Ga}$ ago, at a time of massive volcanism around the world (and hence $\mathrm{CO}_{2}$ release from lavas), there

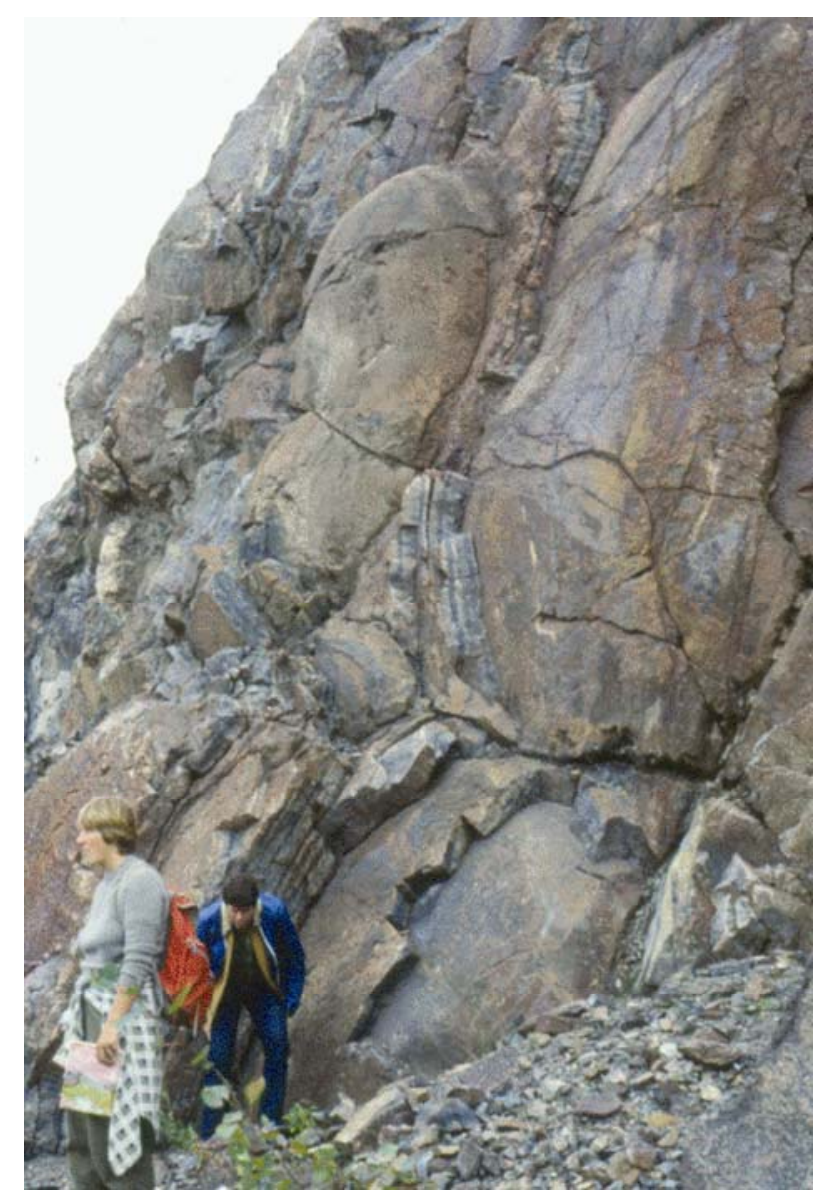

Figure 2 Stromatolites, Steep Rock Lake, NW Ontario, Canada. These $>2.8 \mathrm{Ga}$ stromatolites are laid down unconformably on basement. The carbonate unit is hundreds of metres thick and $>10 \mathrm{~km}$ long, perhaps the oldest preserved carbonate reef. 
is abundant record of stromatolitic limestones. In particular, the $2.7 \mathrm{Ga}$ record shows a wide array of Australian examples as well as the Belingwe stromatolites in Zimbabwe (Figure 3) [8]. The Belingwe rocks include a wide variety of shallow-water sands, shales and limestones, in two separate successions. The $2.7 \mathrm{Ga}$ Manjeri Formation includes small-scale limestone reefs, while the $\sim 2.65$ Ga old Cheshire Formation has luxuriant stromatolite growth in very shallow-water and evaporitic lagoons.

Carbon isotopes from the Belingwe carbonates are most simply explained as the product of oxygenic photosynthesis [8,31]. Carbon isotopes are usually expressed in a delta notation, denoting difference from a carbonate standard in per mil (per thousand) units $(\% \circ)$, where the standard is 0 . In these terms, $\delta^{13} \mathrm{C}_{\text {carbonate }}$ values in the Cheshire carbonates are tightly clustered around $+0.2 \% \circ \pm 0.3 \%$ and $\delta^{13} \mathrm{C}_{\text {organic matter }}$ $-28.6 \% \pm 3.3 \%$. Modern carbonates and organic carbon captured into cells by oxygenic photosynthesis have very similar partitioning of carbon isotopes, and the implication is that organic carbon in the Belingwe rocks was captured from the ocean/atmosphere system by the same processes as today, in consortia sustained by oxygenic photosynthesis. This inference is supported by Mo isotopes, which strongly suggest the water was locally oxic, at least in the Belingwe lagoons [29] and capable of mobilizing Mo during terrestrial weathering. In contrast, shales in the Belingwe rocks appear to have been laid down in anoxic settings (like much modern pond mud) and have much more fractionated car-

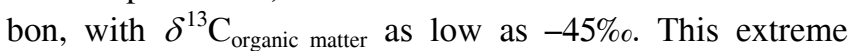
fractionation is typically a sign of methanogenic carbon.

There is ample other evidence of complex Archaean life. Brocks et al. [32] found a wide variety of molecular fossils in bitumens extracted from 2.7 to $2.5 \mathrm{Ga}$ old shales in the Fortescue Group, Pilbara, Australia. If the bitumens are indeed Archaean in age (and not contamination: there is controversy on this point), then hopanes imply bacteria were present. In particular, $2 \alpha$-methylhopanes are evidence for cyanobacteria and hence possibly oxygenic photosynthesis [33]. The ${ }^{33} \mathrm{~S}$ evidence from the $\sim 2.7 \mathrm{Ga}$ record is complex, but also implies episodes in which oxygen was abundant.
For example, this $\mathrm{S}$ isotope evidence has been reported in 2.76 Ga lake sediments in the Pilbara, Australia [30].

The dating of the onset of oxygenic photosynthesis is controversial. Kopp et al. [34] put the evolution of oxygenesis much later, at $\sim 2.3 \mathrm{Ga}$ ago, at the time of a great glaciation. Canfield [5], in a comprehensive and careful review of the debate about the start of oxygenesis, suggests a date of $2.7 \mathrm{Ga}$, possibly earlier, while there is also possible evidence for early oxygenic cyanobacteria [33]. Weighing the diverse evidence, Nisbet et al. [8] preferred a date of $\sim 2.9 \mathrm{Ga}$ ago (Figure 4), though there is the possibility that it is even older. Note that Ohmoto et al. [30] argue for an early start of oxygenesis, which Rosing and Frei place possibly even in the earliest Archaean [22].

Whether or not oxygen was present in the air of $2.9 \mathrm{Ga}$ and $2.7 \mathrm{Ga}$ ago, there is however consensus on one point, that after about $2.3 \mathrm{Ga}$ ago, the air has been oxic. Sometime around 2.3 to $2.4 \mathrm{Ga}$ ago, the $\mathrm{O}_{2}$ content of the air increased strongly and permanently. This has been termed the Great Oxidation Event [5]. Since then, the atmosphere and the uppermost layers of the sea have contained free $\mathrm{O}_{2}$.

\section{Models of the Archaean air}

Models of the Archaean atmosphere are as diverse as the, often contradictory, evidence on which they are based. Figure 4 shows a schematic (and speculative) synopsis of the oxication history of the air [4]. There are some general (though not wholly accepted) points of agreement. Nisbet et al. [8] considered that prior to about $3 \mathrm{Ga}$ ago, the geochemical evidence from sediments implies the air was probably anoxic [11]; after $2.3 \mathrm{Ga}$ ago it has been oxic. In the intervening period, between 2.9 and $2.4 \mathrm{Ga}$ ago, oxygenic photosynthesis appears to have been active and free oxygen may have been present in surface waters, but not in the air. Given the low solubility of $\mathrm{O}_{2}$, the water would have saturated easily.

The greenhouse gas limits are critical to this debate. The modern pre-anthropogenic Earth had from 250-300 parts
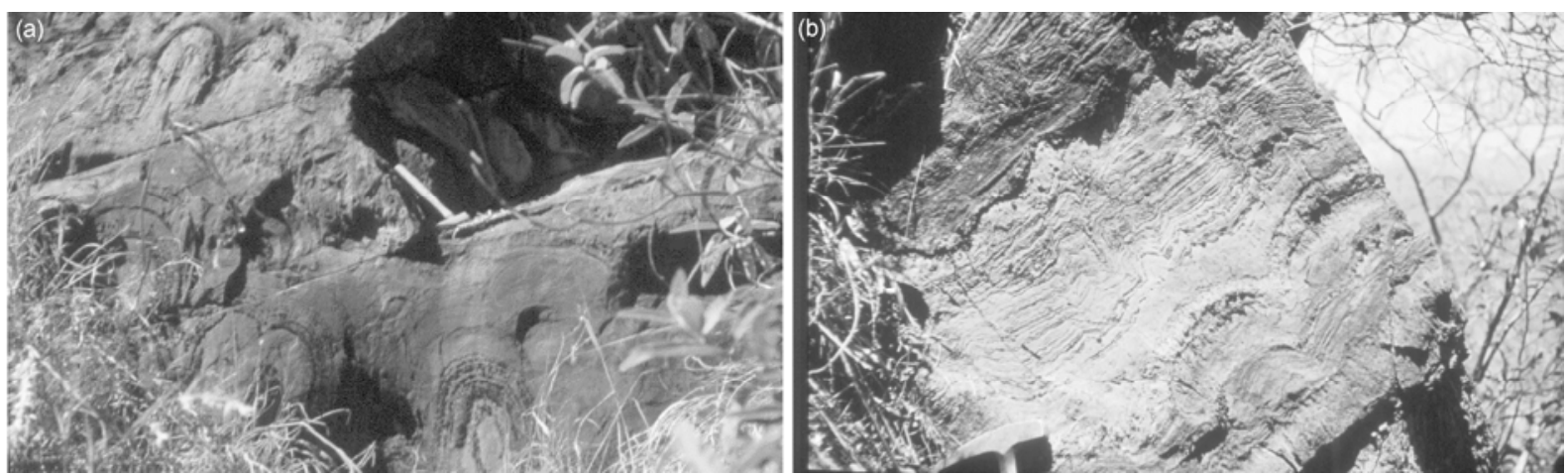

Figure 3 Stromatolites, >2.6 Ga old, in the Cheshire Fm., Belingwe Greenstone belt, Zimbabwe. (a) Outcrop; (b) detail. These shallow-water deposits are very well preserved and show a wide variety of forms. They outcrop along a strike length of kilometers. 


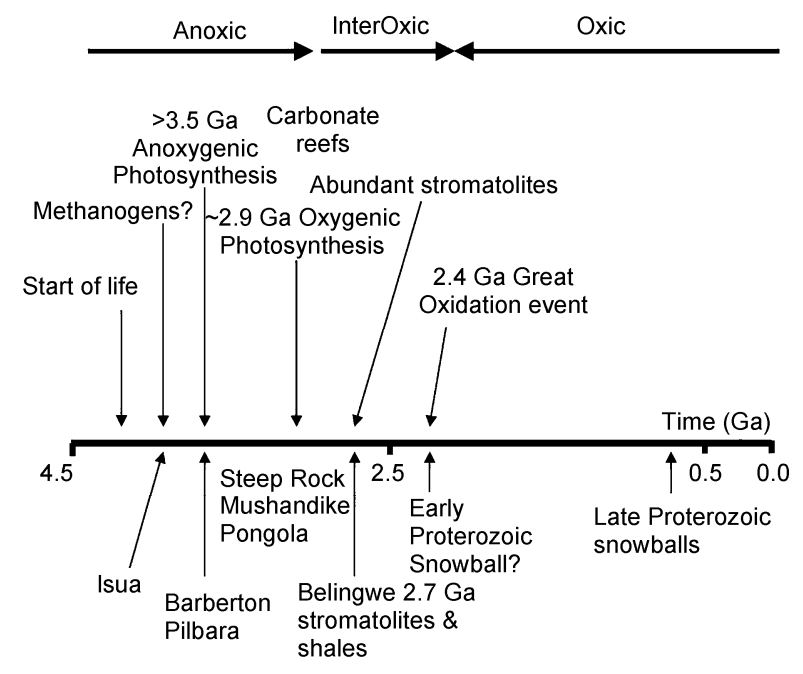

Figure 4 Simplified event chart to show the possible history of oxygen in the air.

per million of pre-industrial $\mathrm{CO}_{2}$ and $\sim 1$ ppm of pre-industrial $\mathrm{CH}_{4}$. These two carbon gases induce evaporation of the main greenhouse gases, water vapour, so that the global temperature is raised from about $-18^{\circ} \mathrm{C}$ to $+15^{\circ} \mathrm{C}$. Today the greenhouse warming increment of the natural (preanthropogenic) air is about $33 \mathrm{~K}$.

In the early Archaean with a much fainter Sun, this increment must have been higher. To maintain a greenhouse warming strong enough to support liquid oceans in Isua (3.8 $\mathrm{Ga}$ ) times, the air probably had abundant $\mathrm{CO}_{2}$ and perhaps (even so early), other biologically managed gases. The most obvious of these is methane, which Lovelock [35] suggested played a major role in planetary management, once life had begun. On the modern Earth, with abundant $\mathrm{CO}_{2}$ in the air but little methane, the incremental impact of adding a molecule of methane to the air is much greater than a molecule of $\mathrm{CO}_{2}$, in terms of blocking the infra-red sky and trapping heat in the atmosphere/ocean system. In the Archaean, with more methane present, this disparity in warming power may have been less, but nevertheless significant.

Rosing et al. [36] pointed out that the ubiquitous presence of mixed-valence Fe (II-III) oxides in the mineralogy of Archaean sediments is difficult to reconcile with the hypothesis of high concentrations of greenhouse gases in the Archaean air. Their suggested way out of this puzzle is that the albedo of the young planet, with small land areas and large oceans may have been lower than now, especially if there were few dust particles and biological aerosols to nucleate clouds. A low-albedo early Earth may have been able to sustain liquid water on its surface, even under the fainter Sun. A higher pressure, with consequent pressure-broadening of the greenhouse warming, may also have contributed to keeping the planet warm.

On the late Hadean Earth there would have been some abiotic methane production, made by water-rock- $\mathrm{CO}_{2}$ reactions around volcanic vents. It is possible that the small amount of methane observed on Mars was made this way and then stored in clathrates, to be released by seasonal warming. But the main source of Earth's methane is biological: reprocessing of biological debris by methanogenic archaea. Today the atmospheric methane budget is almost entirely made by biological sources, either directly or from fires, or from stored methane produced by maturation of carbon rich deposits. Much of the output is directly from methanogenic archaea, either in wetlands or shallow natural gas. Other sources are geological, from geothermal heating of organic matter, but these too recycle organic debris. Methane's lifetime in the air today is about a decade, before the $\mathrm{C}$ atom is oxidised to $\mathrm{CO}_{2}$ and becomes much less potent as a warmer.

In the anoxic Archaean air, methane's lifetime could have been orders of magnitude greater, with the consequence that its atmospheric burden could have built up from sources not greatly larger than today. Once biological carbon capture had begun (for instance by sulphate reduction), geothermal processing of the sedimentary build-up of organic debris would have provided an abundant methane source. Carbon isotope evidence suggests methanogenic archaea, which produce debris very depleted in ${ }^{13} \mathrm{C}$, are very ancient [19]. Once they evolved, recycling of organic debris into methane would have become much more rapid and important than via slow geological maturation. This would have had a strong warming impact.

A productive ecosystem probably existed $3.4 \mathrm{Ga}$ ago [21]. If so, this would likely have been based on anoxygenic photosynthesis under an atmosphere that was oxygen-free. Kharecha et al. [37] modelled such a system, and found that although methane production may have been between a third and 2.5 times modern emission, the atmospheric concentrations of methane in the anoxic early to mid-Archaean air could have been very high, from $100 \mathrm{ppm}$ to as much as $35000 \mathrm{ppm}$ (3.5\%) (Compare this with $\sim 1 \mathrm{ppm}$ in the pre-industrial modern air). Thus the air $3.4 \mathrm{Ga}$ ago may have had high enough greenhouse gas burdens to sustain a warm surface climate, possibly even warmer than today (some suggestions are that the surface temperature was $50-70^{\circ} \mathrm{C}$ ). Moreover, if the methane $/ \mathrm{CO}_{2}$ ratio were high, an atmospheric smog could have developed that blocked incoming ultraviolet light, protecting life on the planetary surface.

By the period between $2.9 \mathrm{Ga}$ ago, and $2.7 \mathrm{Ga}$ ago, a highly productive global ecology may have been established. Figure 5, modified from [35], is a speculative reconstruction of the history of the air, and Figure 6, from [4] shows possible processes in the late Archaean atmosphere. Most of the major biochemical reactions that manage the modern atmosphere were present in the microbial ecology. The air was warm enough to sustain stromatolite reefs of carbonate rock (including limestones) and abundant other water-laid 


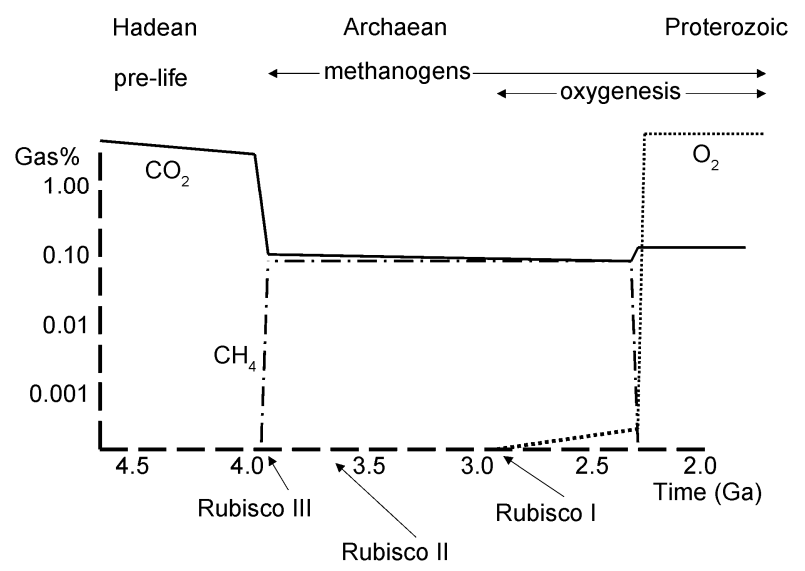

Figure 5 Possible evolutionary history of the air (modified from [35] in [4]).

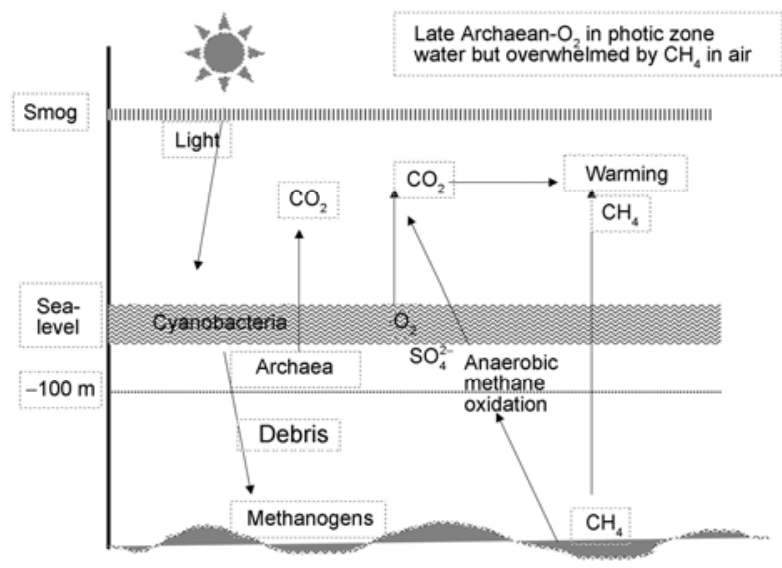

Figure 6 Possible processes in the late Archaean atmosphere. From [4].

deposits. The presence of limestone in the stromatolites suggests water $\mathrm{pH}$ was not especially acid, implying modest $\mathrm{CO}_{2}$ abundance in the air (and probably therefore a methane increment to the greenhouse). In anoxic upwelling waters anoxygenic photoautotrophic bacteria may have catalyzed $\mathrm{Fe}(\mathrm{II})$ oxidation to form $\mathrm{Fe}$ deposits. Figure 7, from [3] shows a synopsis of the conditions.

The evolution of oxygenesis would have challenged this. Free oxygen in the air will eventually reduce the methane lifetime. That cuts the temperature. In short, oxygen emission risks glaciation and shut down of organic productivity. This may have been the cause of the apparent glaciation around $2.9 \mathrm{Ga}$ ago, and also a large scale glacial event about the time of the Great Oxidation Event, 2.3-2.4 Ga ago [4]. This was the birth of the modern oxygen rich air. During the Proterozoic, eukaryote respirers became widespread as plankton. Near the end of the Proterozoic, the greenhouse crashed and major glaciations occurred ("snowball Earth" events). At this stage, the oxygen burden rose further and animal life evolved.

The specificity of Form I rubisco for $\mathrm{CO}_{2}$ appears to be exquisitely tuned to its task $[38,39]$ and may be the key control on the $\mathrm{O}_{2}: \mathrm{CO}_{2}$ ratio of the modern air. Thus rubisco, via the biological productivity that depends on its catalysis, directly controls atmospheric $\mathrm{CO}_{2}$. This implies that rubisco $\mathrm{I}$ is the primary control on the modern atmospheric greenhouse. The second $\mathrm{C}$ greenhouse gas, methane, is a product of anaerobic rubisco III methanogens. These in turn rely on recycling the biological debris that falls to the sea-bed mud and underlying sediment. Most of this debris includes carbon fixed by the productivity of Rubisco I oxygenic photosynthesisers. Finally, the third major biological greenhouse gas, $\mathrm{N}_{2} \mathrm{O}$, depends on the $\mathrm{N}$ cycle and hence nitrogenase. Nitrogenase has been described as evolutionarily crippled, inefficient, yet it is interesting to speculate whether it may also be tuned as finely to its task as rubisco may be.

The biological control on the greenhouse goes further. For a molecule of $\mathrm{CO}_{2}, \mathrm{CH}_{4}$ or $\mathrm{N}_{2}$, the radiative forcing power and hence the Global Warming Potential depends in part on the ambient pressure. Pressure is set by the $\mathrm{N}_{2}$ burden that is mainly maintained by microbial nitrogen fixation, with a minor input also from lightning. Thus there is a feedback between nitrogenase and the greenhouse. Goldblatt et al. [6] assumed a rate of transfer of nitrogen from the ocean crust and sediments to the mantle (subduction minus volcanism) of about $7.5 \times 10^{8} \mathrm{~kg} \mathrm{a}^{-1}, 2 \times 10^{18} \mathrm{~kg} \mathrm{~N}$ would have been subducted to the mantle since $2.7 \mathrm{Ga}$. Subduction rates in the past may well have been higher, so this may represent a lower bound. Thus the atmospheric nitrogen inventory in the late Archean may have been much higher than the present amount [6]. A higher pressure would have enhanced the warming impact of the greenhouse gases, thereby stabilizing the climate.

Finally, water vapour, the most important greenhouse gas, responds to warming by the other gases. Without this natural greenhouse warming, the temperature of the Earth's surface would be around $-18^{\circ} \mathrm{C}$. Water is part of the original chemical inventory of most planetary bodies, but its common phase on the planet's surface - as "rock" (ice), liquid, or gas, or even completely lost to space, depends on the surface temperature. Thus although water is the major greenhouse gas, it is those feedbacks involving the organically produced gases, $\mathrm{CO}_{2}, \mathrm{CH}_{4}$ and $\mathrm{N}_{2} \mathrm{O}$, that manage the abundance of water vapour in the modern air.

On the modern Earth, Rubisco I's molecular specificity [38] is matched on a macro-scale by compensation controls [40]. If there is more $\mathrm{CO}_{2}$ in the air than the compensation limit, and other resources are adequate, then carbon is taken up by photosynthetic cells. Conversely, if there is more $\mathrm{O}_{2}$ than the barrier limit, then it is too disadvantageous to carry out photosynthesis, which is overwhelmed by photorespiration, and net photosynthetic growth ends. There is as yet no full understanding of how the molecular specificity exerted by rubisco is expressed at the macroscopic and global levels via the compensation controls on $\mathrm{O}_{2}$ and $\mathrm{CO}_{2}$. 


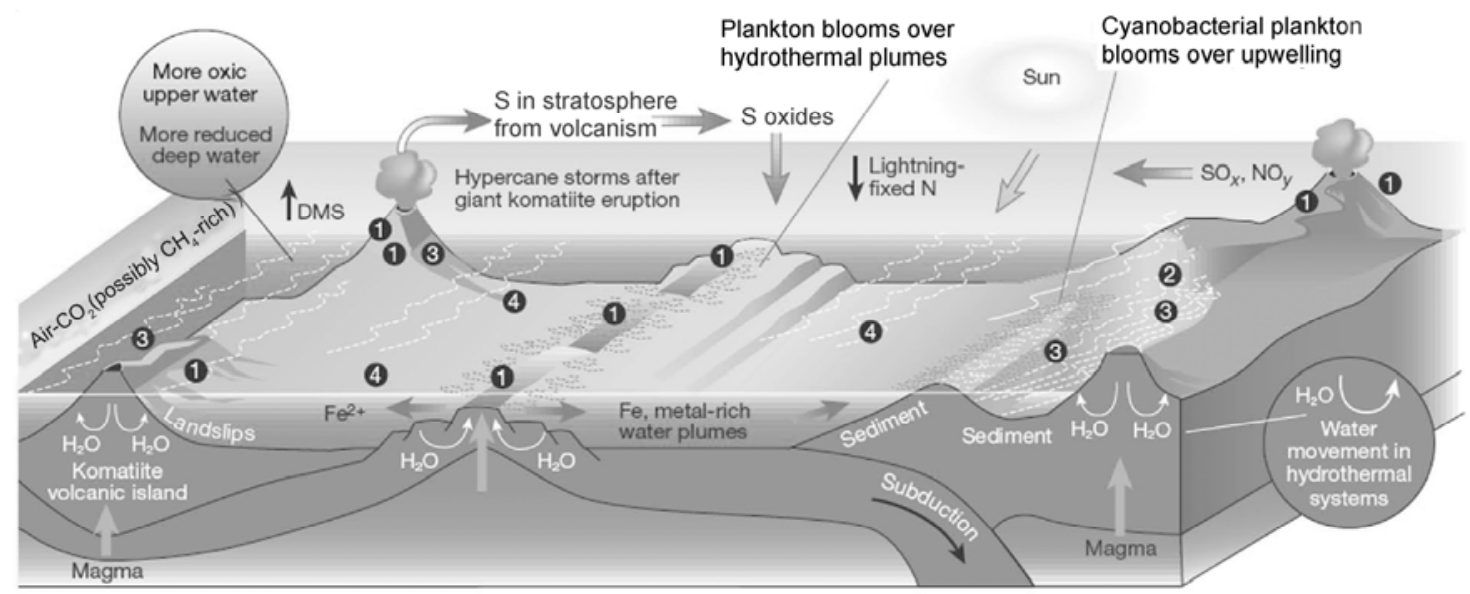

(1) Hyperthermophile biofilms and mats

(2) Anoxygenic photosynthetic mats
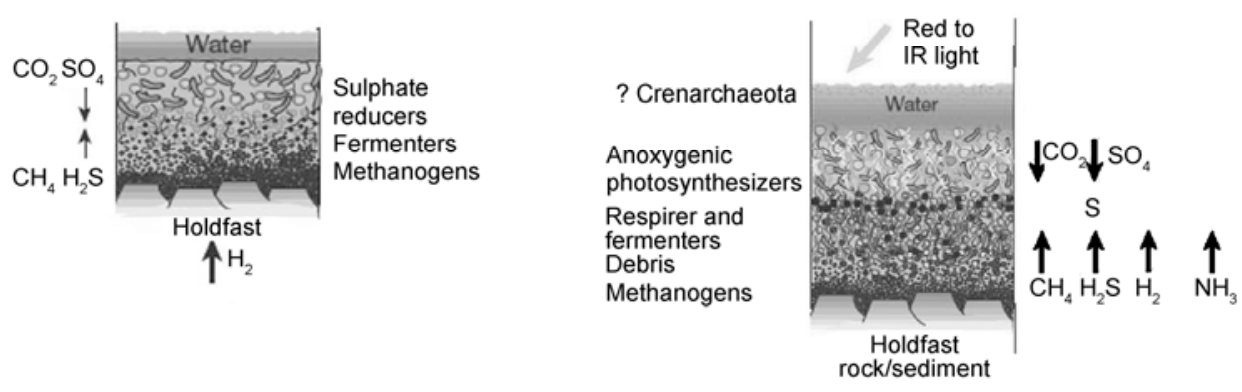

3 Oxygenic photosynthetic mats and stromatolites

(4) Open ocean

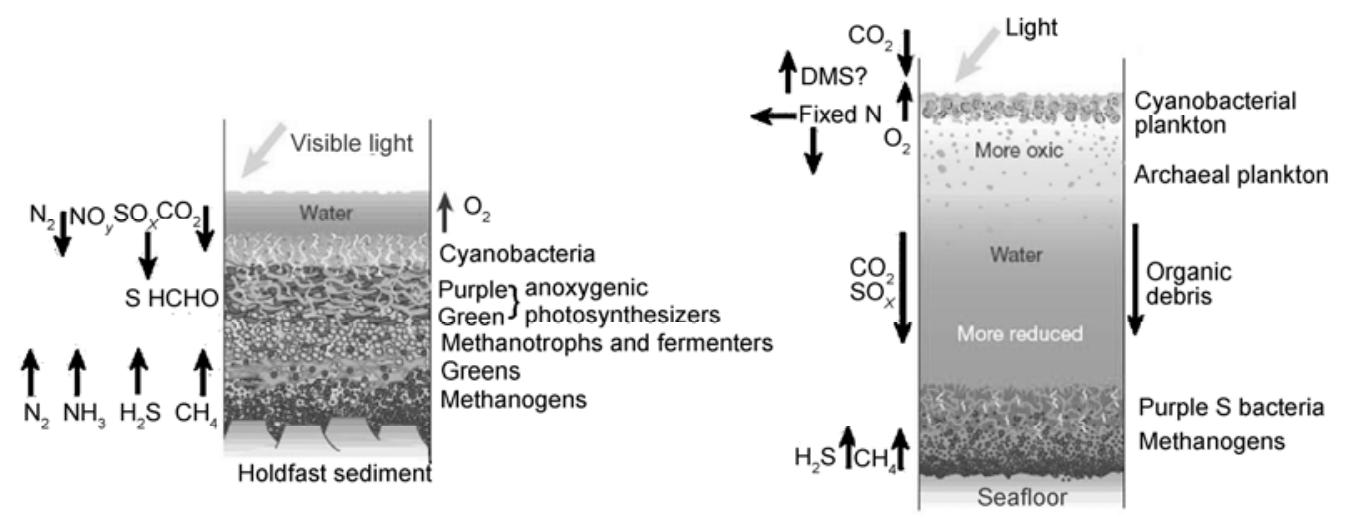

Figure 7 Synopsis of the late Archaean environment. Main diagrasm: general setting. Inset columns: local micro-habitats in microbial mats located in settings indicated by numbers in main diagram. Modified from [3].

The causes of the Great Oxidation Event are much debated [5], and it may have been accompanied by a decline in the amount of the UV-shielding molecule OCS in the air, which would have previously played an important supporting role in maintaining the clement surface conditions [41] under the faint young Sun. There is no consensus, however, on why the atmosphere changed so radically in the Event. Perhaps the Earth system may be bi-stable, with both anoxic and oxic stable states [42]. Yet the primary biochemical reactions of methanogenesis, photosynthesis, and respiration, as well as nitrogen fixation, are very ancient and were likely present in the Archaean. Our modern oxic world is based on that ancient anoxic Archaean ecology.

Thanks to collaborators over the years: Mike Bickle, Tony Martin, the late Paul Abell, Maureen Wilks and Nathalie Grassineau, Norm Sleep, and to Yaoling Niu for suggesting this review.

1 Goldblatt C, Zahnle K J, Sleep N H, et al. The eons of Chaos and Hades. Solid Earth, 2010, 1: 1-3

2 Zahnle K J, Arndt N T, Cockell C, et al. Emergence of a habitable planet. Space Sci Rev, 2007, 129: 35-78

3 Nisbet E G, Sleep N H. The habitat and nature of early life. Nature, 2001, 409: 1083-1091

4 Nisbet E G, Nisbet R E R. Methane, oxygen, photosynthesis, rubisco 
and the regulation of the air through time. Philos Trans Roy Soc Lond B, 2008, 363: 2745-2754

5 Canfield D E. The early history of atmospheric oxygen. Annu Rev Earth Planet Sci, 2005, 33: 1-36

6 Goldblatt C, Matthews A J, Lenton T M, et al. The global nitrogen budget and the Faint Young Sun paradox. Eos Trans AGU, 2008, 89(Suppl): 33D-02

7 Buick R. When did oxygenic photosynthesis evolve? Philos Trans Roy Soc Lond B, 2008, 363: 2731-2744

8 Nisbet E G, Grassineau N V, Howe C J, et al. The age of Rubisco: The evolution of oxygenic photosynthesis. Geobiology, 2007, 5: 311335

9 Nisbet E G, Cann J R, van Dover C L. Origins of photosynthesis. Nature, 1995, 373: 479-480

10 Nisbet E G, Jones S M, Maclennan J, et al. Kick-starting ancient warming: Triggering the Palaeocene/Eocene thermal maximum: The Kilda capacitor hypothesis. Nat Geosci, 2009, 2: 156-159

11 Tabita F R, Hanson T E, Satagopan S, et al. Phylogenetic and evolutionary relationships of RubisCO and the RubisCO-like proteins and the functional lessons provided by diverse molecular forms. Phil Trans R Soc B, 2008, 363: 2629-2640

12 Halliday A N. In the beginning. Nature, 2001, 409: 144-145

13 Sleep N H, Zahnle K, Neuhoff P S. Initiation of clement surface conditions on the earliest Earth. Proc Natl Acad Sci USA, 2001, 98: 3666-3672

14 Compston W, Pidgeon R T. Jack Hills, evidence of more very old detrital zircons in Western Australia. Nature, 1986, 321: 766-769

15 Valley J W, Peck W H, King E M. A cool early Earth. Geology, 2002, 30: 351-354

16 Ryder G. Mass flux in the ancient Earth-Moon system and benign implications for the origin of life on Earth. J Geophys Res, 2002, 107: 5022

17 Bowring S A, Williams I S. Priscoan (4.00-4.03 Ga) orthogneisses from northwestern Canada. Contrib Mineral Petrol, 1999, 134: 3-16

18 Rosing M T. ${ }^{13} \mathrm{C}$-depleted carbon in $>3700 \mathrm{Ma}$ seafloor sedimentary rocks from West Greenland. Science, 1999, 283: 674-676

19 Grassineau N V, Abell P, Appel P W U, et al. Early life signatures in sulphur and carbon isotopes from Isua, Barberton, Wabigoon (Steep Rock) and Belingwe greenstone belts (3.8 to $2.7 \mathrm{Ga}$ ). In: Kesler S E, Ohmoto H, eds. Evolution of Early Earth's Atmosphere, Hydrosphere and Biosphere-Constraints from Ore Deposits. Geol Soc Am Spec Pub, 2006, 198: 33-52

20 Allwood A C, Walter M R, Kamber B S, et al. Stromatolite reef from the Early Archaean era of Australia. Nature, 2006, 441: 714-718

21 Tice M M, Lowe D R. Photosynthetic microbial mats in the 3416-Myr-old Ocean. Nature, 2004, 431: 549-552

22 Rosing M T, Frei R. U-rich Archaean sea-floor sediments from Greenland - indications of $>3700$ Ma oxygenic photosynthesis. Earth Planet Sci Lett, 2004, 6907: 1-8

23 Hessler A M, Lowe D R, Jones R L, et al. A lower limit for atmospheric carbon dioxide levels 3.2 billion years ago. Nature, 2004, 428: 736-738

24 Farquhar J, Wing B A. Multiple sulfur isotopes and the evolution of the atmosphere. Earth Planet Sci Lett, 2003, 213: 1-13

25 Lowe D R, Tice M M. Tectonic controls on atmospheric, climatic and biological evolution 3.5-2.4 Ga. Precambrian Res, 2007, 158: 177197

26 Wilks M E, Nisbet E G. Archaean stromatolites from the Steep Rock Group, N.W. Ontario. Can J Earth Sci, 1985, 22: 792-799

27 Eglington B M, Talma A S, Marais S, et al. Isotopic composition of Pongola Supergroup limestones from the Buffalo River gorge, South Africa. South Afr J Geol, 2003, 106: 1-10

28 Abell P I, McClory J, Martin A, et al. Petrography and stable isotope ratios from Archean stromatolites, Mushandike Fm., Zimbabwe. Precambrian Res, 1985, 27: 385-398

29 Siebert C, Kramers J D, Meisel T, et al. PGE, Re-Os, and Mo isotope systematics in Archean and early Proterozoic sedimentary systems as proxies for redox conditions of the early Earth. Geochim Cosmochim Acta, 2005, 69: 1787-1801

30 Ohmoto H, Watanabe Y, Ikemi H, et al. Sulphur isotope evidence for an oxic Archaean atmosphere. Nature, 2006, 442: 908-911

31 Grassineau N V, Nisbet E G, Fowler C M R, et al. Stable isotopes in the Archaean Belingwe belt, Zimbabwe: Evidence for a diverse microbial mat ecology. In: Fowler C M R, Ebinger C J, Hawkesworth C J, eds. The Early Earth: Physical, Chemical and Biological Development. Geol Soc London Spec Pub, 2002, 199: 309-328

32 Brocks J J, Buick R, Summons R E, et al. A reconstruction of Archean biological diversity based on molecular fossils from the 2.78 to 2.45 billion-year-old Mount Bruce Supergroup, Hamersley basin, Western Australia. Geochim Cosmochim Acta, 2003, 67: 4321-4335

33 Summons R E, Jahnke L L, Hope J M, et al. 2-Methylhopanoids as biomarkers for cyanobacterial oxygenic photosynthesis. Nature, 1999, 400: 554-557

34 Kopp R E, Kirschvink J L, Hilburn I A, et al. The Paleoproterozoic snowball Earth: A climate disaster triggered by the evolution of oxygenic photosynthesis. Proc Natl Acad Sci USA, 2005, 102: 11131-11136

35 Lovelock J. The Ages of Gaia. New York: W W Norton, 1988. 252

36 Rosing M T, Bird D K, Sleep N H, et al. No climate paradox under the faint early Sun. Nature, 2010, 464: 744-747

37 Kharecha P, Kasting J, Siefert J. A coupled atmosphere-ecosystem model of the early Archean Earth. Geobiology, 2005, 3: 53-76

38 Tcherkez G G B, Farquhar G D, Andrews T J. Despite slow catalysis and confused substrate specificity, all ribulose bisphospahte carboxylases may be nearly perfectly optimized. Proc Natl Acad Sci, 2006, 103: 7246-7251

39 Gutteridge S, Pierce J. A unified theory for the basis of the limitations of the primary reaction of photosynthetic $\mathrm{CO}_{2}$ fixation: Was Dr. Pangloss right? Proc Natl Acad Sci USA, 2006, 103: 7203-7204

40 Tolbert $\mathrm{N}$ E, Benker $\mathrm{C}$, Beck E. The oxygen and carbon dioxide compensation points of $\mathrm{C}_{3}$ plants: Possible role in regulating atmospheric oxygen. Proc Natl Acad Sci USA, 1995, 92: 11230-11233

41 Ueno Y, Johnson M S, Danielache S D, et al. Geological sulfur isotopes indicate elevated OCS in the Archean atmosphere, solving faint young sun paradox. Proc Natl Acad Sci USA, 2009, 106: 14784-14789

42 Goldblatt C, Lenton T M, Watson A J. Bistability of atmospheric oxygen and the great oxidation. Nature, 2006, 443: 683-686

Open Access This article is distributed under the terms of the Creative Commons Attribution License which permits any use, distribution, and reproduction in any medium, provided the original author(s) and source are credited. 